\title{
Granulocyte colony-stimulating factor expression as a prognostic biomarker in non-small cell lung cancer
}

\author{
G.P. STATHOPOULOS ${ }^{1}$, A. ARMAKOLAS ${ }^{2}$, T. TRANGA ${ }^{3}$, \\ H. MARINOU ${ }^{1}$, J. STATHOPOULOS ${ }^{1}$ and H. CHANDRINOU ${ }^{1}$ \\ ${ }^{1}$ First Oncology Clinic, Errikos Dunant Hospital, Athens; ${ }^{2}$ Labotarotory of Experimental \\ Physiology, University of Athens; ${ }^{3}$ Bioanalytica-Genotype S.A., Athens, Greece
}

Received October 20,2010; Accepted December 17, 2010

DOI: $10.3892 / o r .2011 .1226$

\begin{abstract}
Hematologic paraneoplastic alternations may not be very common, but they have been observed in a small number of patients. Granulocytosis has been described in several malignancies and its common mechanism may be associated with granulocyte colony-stimulating factor (G-CSF) production by the tumor. High neutrophilia $(150,000-240,000$ white blood cell count) observed in two patients with non-small cell lung cancer led us to run the present trial. The purpose of this study was to compare the white blood cell counts and the G-CSF plasma levels of the patients and classify the results into groups, as well as to determine the survival rates of the patients in each of the groups. The histological specimens and plasma of two patients as well as the plasma of another 87 patients with several malignancies, were examined. The plasma G-CSF levels were determined using a quantitative sandwich immunoassay technique (Quantikine; RYSD Systems) according to the manufacturer's instructions and all samples were tested in triplicate. It was found that 12 patients had a white blood cell count increased beyond normal as well as a high G-CSF plasma level and the survival of these patients was shorter as compared to the rest of the patients. We assume that these findings may indicate that increased G-CSF levels may function as a biomarker of survival.
\end{abstract}

\section{Introduction}

Hematologic paraneoplastic alterations may not be very common but they are observed in a small number of patients. The white blood cell count may often increase to a small degree due to different causes such as infections or after the injection of granulocyte colony-stimulating factor (G-CSF). A white blood cell count more than $50 \times 10^{9} / 1$ not related to bone marrow involvement, is considered as a leukemoid

Correspondence to: Dr G.P. Stathopoulos, Semitelou 2A, 11528 Athens, Greece

E-mail: dr-gps@ath.forthnet.gr

Key words: granulocyte colony-stimulating factor, prognostic factor reaction and this is observed in a variety of clinical settings (1). Granulocytosis has been described in Hodgkin's disease, lymphomas, solid tumors, gastric, lung, pancreatic cancers, brain tumors and melanoma. The common mechanism of granulocytosis associated with the tumor is the production of growth factors by the tumor (2). There are studies suggesting that hematopoietic growth factors act as an autocrine stimulator of colony-stimulating factor (CSF)-producing tumor cells, which promote the progression of the tumor (3-5). Various human hematopoietic growth factors stimulate clonal growth of non-hematopoietic tumor cells (6). Granulocytemacrophage colony-stimulating factor (GM-CSF) is usually produced and secreted by the stromal cells in the bone marrow, but may occasionally be secreted by lymphocytes and macrophages following endotoxic stimulation (7-9).

The undertaking of the present study was prompted by the fatal outcome of two patients with non-small cell lung cancer (NSCLC) who presented with an extreme increase in their white blood cell counts.

We examined the histological specimens for G-CSF expression in these two patients and we investigated the plasma G-CSF in patients with NSCLC and other malignancies in relation to the white blood cell count level and determined the significance of elevated G-CSF in plasma levels.

\section{Patients and methods}

Two patients with a very high white blood cell count mainly presenting with an increase in neutrophils are described in detail. The histological tumor specimens of these patients were examined for G-CSF expression. The blood G-CSF levels were also determined. In a total of 89 patients with a variety of malignant tumors the G-CSF levels were calculated in blood samples. A small number of these 89 patients had an increased white blood cell count (Table I).

Plasma G-CSF levels were determined using a quantitative sandwich immunoassay technique (Quantikine; RYSD Systems) according to the manufacturer's instructions and all samples were tested in triplicate. Briefly, $100 \mu \mathrm{l}$ of the sample was added to $100 \mu \mathrm{l}$ of dilluent/well of the ELISA plate and they were incubated for $2 \mathrm{~h}$ at room temperature. After washing the wells three times, $200 \mu \mathrm{l}$ of G-CSF conjugate were added to each well followed by a $2-\mathrm{h}$ incubation. Then 
Table I. G-CSF plasma levels classified.

\begin{tabular}{|c|c|c|c|}
\hline G-CSF & $\begin{array}{l}\text { No. of } \\
\text { patients }\end{array}$ & $\begin{array}{l}\text { White blood } \\
\text { cells }\end{array}$ & $\begin{array}{l}\text { Survival } \\
\text { time }\end{array}$ \\
\hline Up to $100 \mathrm{pg} / \mathrm{ml}$ & 54 & $4-10,000$ & $\begin{array}{l}\text { Median } 12 \text { months } \\
\text { Range 6-20 months }\end{array}$ \\
\hline$>100 \mathrm{pg} / \mathrm{ml}$ & 23 & $8-12,000$ & $\begin{array}{l}\text { Median } 9 \text { months } \\
\text { Range 6-14 months }\end{array}$ \\
\hline$>200 \mathrm{pg} / \mathrm{ml}$ & 9 & $10-20,000$ & $\begin{array}{l}\text { Median } 7 \text { months } \\
\text { Range 5-8 months }\end{array}$ \\
\hline$>1000 \mathrm{pg} / \mathrm{ml}$ & $\begin{array}{l}1 \\
1 \\
1\end{array}$ & $\begin{array}{l}22,000 \\
150,000 \\
240,000\end{array}$ & $\begin{array}{l}3 \text { months } \\
1 \text { week } \\
1 \text { week }\end{array}$ \\
\hline
\end{tabular}

$200 \mu \mathrm{l}$ of substrate was added in each well followed by a 25-min incubation at room temperature. The reaction was terminated by the addition of $50 \mathrm{ml}$ stop buffer ( $2 \mathrm{M}$ sulphuric acid) and the color intensity was measured in each case at $450 \mathrm{~nm}$ using a microplate reader (Versamax, Molecular Devices). The correction of the obtained values was carried out by subtracting the readings from $450 \mathrm{~nm}$ from the reading at 540 as indicated by the manufacturer of the kits.

For the immunohistochemical analysis, formaldehyde-fixed lung samples were paraffin-wax embedded and processed for paraffin sections. Microtome sections of $3 \mu \mathrm{m}$ were allowed to adhere to the glass slides and dried at $37^{\circ} \mathrm{C}$ overnight, dewaxed in xylene and rehydrated in serial dilutions of ethanol. The tissue also underwent heat-mediated antigen retrieval in sodium citrate buffer ( $\mathrm{pH}$ 6.0). The sections were then incubated with a primary species (rabbit) anti-human G-CSF antibody at a dilution of $1 / 30$ in PBS overnight at $4^{\circ} \mathrm{C}$. Secondary biotinylated goat anti-rabbit IgG antibody (Dako Real EnVision, Glostrup, Denmark) was then added and tissue sections were visualized under light microscopy, while negative control staining procedures were also included in all immunohistochemical analyses, as described above.

\section{Case presentations}

Case A. A 53-year-old male was admitted to the hospital because of central nervous system symptomatology. The CT and MRI scans showed a single brain tumor and lung opacity. Computerized tomography showed an abnormal shade at the right hilum and enlargement of the mediastinal lymph nodes. The brain MRI showed a single tumor, which was surgically excised. The histological specimen confirmed metastatic adenocarinoma with the lung as the primary site. The lung tumor histology was also adenocarcinoma. After recovery from the brain surgery, the patient remained in reasonably good condition. His blood test, liver function tests, blood urea, blood glucose and serum creatinine were within normal limits. The patient was then given chemotherapy with $80 \mathrm{mg} / \mathrm{m}^{2}$ of cisplatin and $1 \mathrm{gr} / \mathrm{m}^{2}$ of gemcitabine every 3 weeks, a treatment which he tolerated very well, with only minor side effects. He underwent 3 courses of chemotherapy within 6 weeks. One week after the last treatment the blood count showed a high increase in the white blood cell count $(120,000 / \mathrm{dl})$ with a major increase in neutrophils. No supportive granulocyte growth factor treatment was given for prophylaxis after the chemotherapy course. The corticosteroid, dexamethasone, was given only on the day he underwent chemotherapy, as antiemetic and antiallergic protection. Nine days after treatment the blood cell count increased further to $240,000 / \mathrm{dl}$. Gemcitabine only was then infused. Two days later the patient passed away suddenly with rapidly increasing respiratory insufficiency. No further blood tests were done. The histology specimen was examined for G-CSF expression.

Case B. A 64-year-old male patient was admitted to the hospital for dyspnea and cough. His past history included only mild hypertension. The patient was examined with full blood count, liver function tests, blood glucose, blood urea and serum creatinine which were normal. Computed tomography of the chest, abdomen and brain showed a tumor mass at the right lung hilum extending to the upper lobe. Mediastinal lymph nodes were abnormally enlarged. There was also a suspicious nodule at the right adrenal gland. The brain and skeleton were free of disease. The lung tumor was considered to be inoperable; histology taken by bronchoscopy showed adenocarcinoma of high differentiation. The patient was put on chemotherapy with $135 \mathrm{mg} / \mathrm{m}^{2}$ of paclitaxel and $200 \mathrm{mg} / \mathrm{m}^{2}$ of liposomal cisplatin administered every 2 weeks. No serious side effects were observed. The white blood cell counts were normal and a very mild reduction was observed after treatment. The plan was to administer 9 courses since the drugs were given every 2 weeks at a lower dosage than that of every 3 weeks. The only side effect was unacceptable peripheral neuropathy as a result of the paclitaxel administration; after the 7 th course $1 \mathrm{gr} / \mathrm{m}^{2}$ of gemcitabine was given instead of paclitaxel. There was a partial response but still the tumor was inoperable. Soon the patient again started experiencing dyspnea and tiredness and he was admitted to hospital. One particular finding apart from lung disease progression was a very high increase in the patient's white blood cell count (150,000 with $90 \%$ neutrophils). Two days later he passed away.

Cases $A$ and B. Laboratory findings. In the above two patients with leucocytosis neutrophilia, a bone-marrow examination of certain genes was performed in order to detect any indication of leukemia. For the investigation of V617F of JAK 2 gene mutation the quantitative Real-Time PCR (qRT-PCR) method was performed. Isolation of RNA was first done using QTAamp RNA blood Mini Kit (Qiagen), then reverse transcription, sequencing using the Light Cycler $\mathrm{t}(9 ; 22) \mathrm{Kit}$ and Light Cycler 2 (Roche). The isolation of hybrid transcript b3a2, b2a2, ela2 as well as b2a3 and b3a3 was done. As reference transcript was used the G6PDH, and as positive control the RNA of the cell line K562 (human myelogenous leukemia cell line), where the percentage of hybrid gene BCR/ABL in relation of the reference gene G6PDH is $100 \%$.

The next investigation was to examine the G-CSF expression in the histological specimens of the cases presented. According to the literature, G-CSF may be considered as a biomarker for cancer $(4,6)$. This indication led us to examine the plasma G-CSF levels of the patients, some of whom 


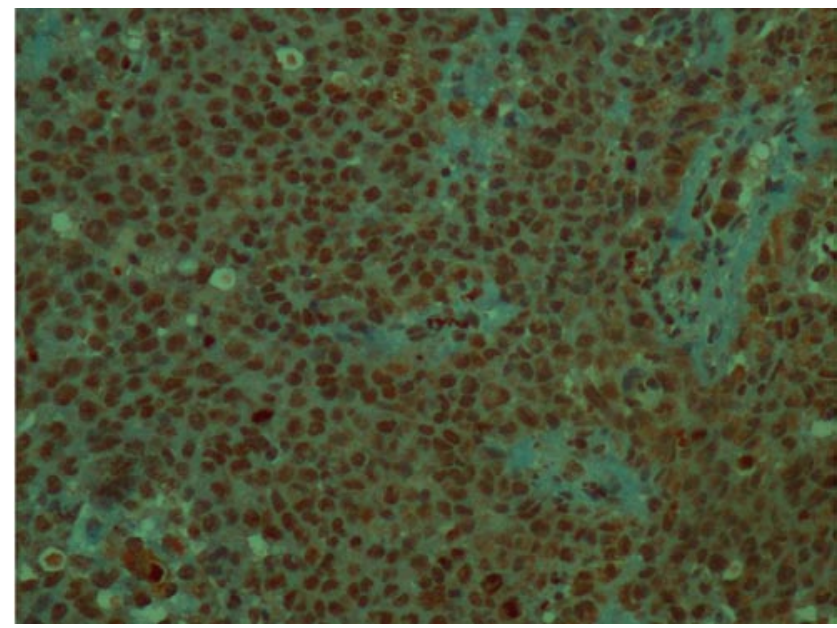

Figure 1. Increased G-CSF expression in the histological specimen of case A.

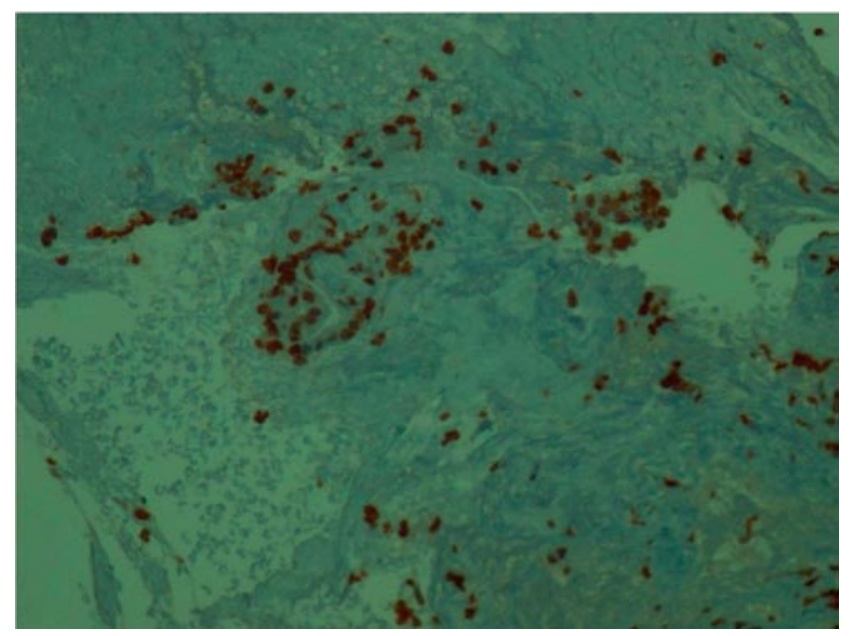

Figure 2. Increased G-CSF expression in the histological specimen of case B.

had a higher than normal white blood cell count level and neutrophils (Table I). Eighty-nine patients with lung cancer and other different malignancies were examined and the results showed that the great majority of these patients had a low level of G-CSF.

\section{Results}

We classified the plasma levels of G-CSF in four groups, measuring the values up to $100 \mathrm{pg} / \mathrm{ml}$, higher than $100 \mathrm{pg} / \mathrm{ml}$, higher than $200 \mathrm{pg} / \mathrm{ml}$, and higher than $1,000 \mathrm{pg} / \mathrm{ml}$. It was determined that out of the 89 patients examined $54(60.67 \%)$ had a plasma G-CSF concentration of under $100 \mathrm{pg} / \mathrm{ml}, 23$ (25.84\%) patients above $100 \mathrm{pg} / \mathrm{ml}, 9(10.11 \%)$ over $200 \mathrm{pg} / \mathrm{ml}$ and $3(3.37 \%)$ over $1,000 \mathrm{pg} / \mathrm{ml}$. The latter 3 patients included the 2 who were previously described with the extremely increased cell count. Table I shows the survival rate of patients with high G-CSF expression.

The results of the histological examination for G-CSF expression done on the two cases with high levels of neutrophilia described here, also showed a high level of G-CSF expression in the tumor. This was compared histologically

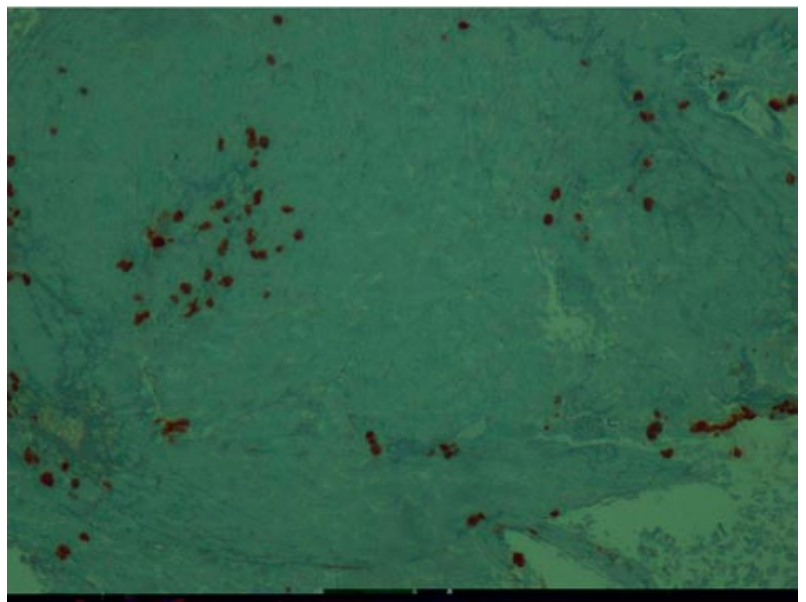

Figure 3. No expression of G-CSF in normal lung tissue.

with normal lung tissue, where no G-CSF was expressed. The specimens under examination were negative for the BCR/ABL gene. This finding excluded leukemia as a cause of neutrophilia in the two patients described. Figs. 1 and 2 show the increased G-CSF expression in their histological specimens. Fig. 3 shows no expression of G-CSF in normal lung tissue.

\section{Discussion}

G-CSF is a pleiotropic cytokine best known for its specific effects on the proliferation and activation of hematopoietic cells of the neutrophilic granulocyte lineage. It is produced by activated monocytes/macrophages, fibroblasts, endothelial cells, astrocytes, osteoblasts and bone marrow stromal cells. G-CSF and G-CSF receptors have also been shown to be produced by placental, decidual and endometrial gland cells during pregnancy, suggesting that G-CSF may play a role in decidual and placental functions (10). Clinical use of G-CSF has been approved for the amelioration of chemotherapyinduced neutropenia as well as for severe chronic neutropenia following bone marrow transplants. Several studies on G-CSF and its clinical applications have been published (11-15).

The findings of the present study may be interpreted to mean that plasma and tumor G-CSF may be of a value as a prognostic marker in patients who have an abnormal increase in their white blood cell counts. The fact that in the present study 12 patients with neutrophilia had a survival of short duration makes the determination of G-CSF levels an important factor to be considered.

\section{References}

1. Jardin F, Vasse M, Debled M, Dominique S, Courville F, Callonnec F, Buchonnet G, Thiberville L and Tilly H: Intense paraneoplastic neutrophilic leukemoid reaction related to a G-CSF secreting lung sarcoma. Am J Hematol 80: 243-245, 2005.

2. Robinson WA: Granulocytosis in neoplasia. Ann NY Acad Sci 230: 212-215, 1974.

3. Nakada T, Sato H, Inoue F, Mizorogi F, Nagayama K and Tanaka T: The production of colony-stimulating factors by thyroid carcinoma is associated with marked neutrophilia and eosinophilia, case report. Intern Med 35: 815-820, 1996. 
4. Baldwin GC, Gasson JC, Kaufman SE, Quan SG, William RE, Avalos BR, Gazdar AF, Golde GC and Dipersio JF: Nonhematopoietic tumor cells express functional GM-CSF receptors. Blood 73: 1033-1037, 1989.

5. Thacker JD, Dedhar S and Hogge DE: The effect of GM-CSF and G-CSF on the growth of human osteosarcoma cells in vitro and in vivo. Int J Cancer 56: 236-243, 1994.

6. Berdel WE, Danhauser-Riedl S, Steinhauser G and Winton EF: Various human hematopoietic growth factors (interleukin-3, GM-CSF, G-CSF) stimulate clonal growth of non-hematopoietic tumor cells. Blood 73: 80-83, 1989.

7. Watanabe M, Ono K, Ozeki Y, Tanaka S, Aida S and Okuno Y: Production of granulocyte-macrophage colony-stimulating factor in a patient with metastatic chest wall large cell carcinoma. Jpn J Clin Oncol 28: 559-562, 1998.

8. Gasson JC, Weisbart RH, Kaufman SE, Clark SC, Hewick RM, Wong GG and Golde DW: Purified human granulocyte-macrophage colony-stimulating factor: direct action on neutrophils. Science 224: 1339-1341, 1984

9. Antman KS, Griffin JD, Elias A, Socinski MA, Ryan L, Cannistra SA, Dette D, Whitley M, Emilfrei RN and Schnipper LE: Effect of recombinant human granulocytemacrophage colony-stimulating factor on chemotherapy-induced myelosuppression. N Engl J Med 319: 593-598, 1988.
10. Saito S, Fukunag R, Ichijo $M$ and Nagata S: Expression of granulocyte colony-stimulating factor and its receptor at the fetomaternal interface in murine and human pregnancy. Growth Factors 10: 135-143, 1994.

11. Nagata S: Granulocyte colony-stimulating factor. In: Handbook of Experimental Pharmacology Peptide Growth Factors and Their Receptors. Sporn MB and Roberts AB (eds). SpringerVerlag, Berlin, p699, 1990.

12. Gabrilove JL: Clinical applications of granulocyte colonystimulating factor (G-CSF). Growth Factors 6: 187-191, 1992.

13. Nagata S: Cytokine colony-stimulating factor. In: The Cytokine Handbook. Thomson AW (ed). Academic London, pp371-385, 1994.

14. Felser JM: Clinical use of hematopoietic growth factors for control of infections after high-dose chemotherapy. Ann NY Acad Sci 730: 235-242, 1994.

15. Harmenberg J, Hoglund M and Hellstrom-Lindberg E: G- and GM-CSF in oncology and oncological haematology. Eur J Haematol (Suppl.) 55: 1-28, 1994. 